\title{
The Effect of Gender, Locus of Control, Love of Money, and Economic Status on Students' Ethical Perception
}

\author{
Khanifah Khanifah ${ }^{1}$, Jaka Isgiyarta ${ }^{2}$, Indah Lestari ${ }^{3} \&$ Udin $_{\text {Udin }}{ }^{4}$ \\ ${ }^{1}$ Ph.D Scholar at Universitas Diponegoro, Universitas Wahid Hasyim, Indonesia \\ ${ }^{2}$ Universitas Diponegoro, Indonesia \\ ${ }^{3}$ Universitas Wahid Hasyim, Indonesia \\ ${ }^{4}$ Universitas Muhammadiyah Yogyakarta, Indonesia \\ Correspondence: Udin Udin, Universitas Muhammadiyah Yogyakarta, Jl. Brawijaya, Geblagan, Yogyakarta, \\ Indonesia. E-mail: udin_labuan@yahoo.com
}

Received: July 25, 2019

Accepted: August 23, 2019

Online Published: August 24, 2019

doi:10.5430/ijhe.v8n5p168

URL: https://doi.org/10.5430/ijhe.v8n5p168

\begin{abstract}
This study aims to examine the effect of gender, locus of control, love of money, and economic status on students' ethical perception. This study uses primary data obtained from the distribution of questionnaires to the students of accounting programs at higher education in Semarang - Indonesia. Purposive sampling is used to select 104 respondents to participate in the study. Data is analyzed using multiple linear regression with applying for IBM SPSS 21 program. The results reveal that gender and internal locus of control have a positive effect on students' ethical perception. Love of money further has a negative effect on students' ethical perception. In contrast to the expectation, economic status has no effect on students' ethical perception.
\end{abstract}

Keywords: gender, locus of control, love of money, economic status, ethical perception

\section{Introduction}

Since there have been many scandals in business, there has also been increasing public attention to ethical issues in business and the profession. It has happened in the accounting profession which has resulted in decreased public trust. This is due to the emergence of major case scandals in financial carried out by large companies that involve the office of accountants and accounting professionals. The existence of these cases led to public trust in the accounting profession and it still much-discussed (Tripermata, 2016).

Accountants are considered as a profession that is very vulnerable to fraudulent work. An accountant is required to have high objectivity to act fairly. Besides, an accountant must also have independence so that he/she is not easily influenced by other parties in making decisions to avoid cheating. Therefore, that way of an accountant will get the trust of the public who uses his/her services (Charismawati, 2011).

O'Leary and Cotter (2000) say that ethics is an issue at the forefront to be discussed in every discussion relating to the world professionalism of accounting and auditing. The ethical behavior of a professional accountant is very important to determine the status and credibility of the profession (Chan dan Leung, 2006). The accounting profession emphasizes the importance of professionals developing ethical behavior starting from the beginning of their careers, even before they are involved in the profession (Elias and Farag, 2010). Accounting Education Change Commission (AECC) (1990) also states that one of the intellectual skills that must be possessed by accounting graduates is the ability to identify ethical problems and apply value-based reasoning systems to ethical questions related to the accounting profession. Mintz (1995) mentions the importance of good qualities that must exist in the accounting profession. He explained that these virtues made an accountant able to withstand client pressures resulting from conflicts between the obligations of an accountant to the client or the consideration of the company's leadership and the public interest.

Basri (2015) states that from the many accounting scandals that occur can tarnish the position of the accounting profession, such as the scandal that was carried out by Enron and Worldcom companies that manipulated financial statements. The scandal certainly raises a question about professional ethics that is owned by an accountant. This case involved a well-known KAP in the United States, Arthur Andersen. 
Another recent scandal in 2017 happened to Toshiba Corp. technology company that involved the leadership and accounting department. The company overestimates the income statement. Toshiba accounting scandals are estimated to reach more than USD 1 billion. Financial scandals carried out by figures of the accounting profession raise ethical doubts held by an accountant (Pradanti and Prastiwi, 2014). The existence of the violation case reinforces the need for the accountant's professional awareness of ethics. It's not just the skills and special intelligence possessed by an accountant, but also ethical attitudes are needed (Himmah, 2018).

Various cases of violations that have occurred make it aware that knowledge about ethics in accounting education is very important (Basri, 2015). Accounting students are professionals in the future and with good ethical education, they are expected to benefit the profession in the long run. Then education about ethics must be done right for accounting students before they enter the workforce. One of the objectives of accounting education is to introduce students to ethical values and standards in the accounting profession.

The ethical behavior of a person who can be determined by the educational environment makes education about ethics important to be invested in accounting students since they are still in the educational environment, namely on campus (Fatoki, 2015). This is done so that before entering the workforce they already have good ethics and later in the future, it will be applied in their work.

Overall this study is a compilation of research (Lucyanda and Endro, 2014) which examines the influence of gender on ethical perception of accounting and research students (Purnamaningsih and Ariyanto, 2016) who examine love of money and locus of control. The difference in this research with previous research is to add economic status by assuming that different economic statuses will form different personalities that affect one's ethical perception.

\section{Literatur Review}

\subsection{Ethical Perception}

The term "perception" means vision, response, and power to understand or respond to something that begins with the senses which is transferred to the brain. Ethics are values or norms that become a guideline for each individual. Ethical perception is a combination of perception and ethics. Based on the definition of perception and ethics, ethical perception is defined as the process of how one selects, regulates and interprets the input of information and experiences that exist and then interprets it to create the overall meaning contained in it in accordance with the principles of truth, character, and moral applies (Robbins and Judge, 2008). It can be concluded that ethical perception is an assumption or a person's thinking based on one's moral values. In this study, ethical perception is one's view of seeing accounting fraud. Perception is influenced by three factors namely situation factors, perception factors, and object factors (Robbins and Judge, 2008).

In the Charismawati (2011) study, what is meant by ethical perception is how one behaves and evaluates a violation condition or behavior. Uddin and Gillett (2002) examine ethical perception using scenarios. In the study, they examined the relationship between moral reasoning and monitoring of the chief financial officer (CFO) on ethical perception of violations. The study has four independence scenarios. Scenario 1 discusses the initial introduction of income (earnings management), scenario 2 handles the problem by classifying current long-term securities to increase the current ratio, scenario 3 is the recognition of several consignment inventories as assets, and scenario 4 discusses the reporting of unconditional obligations (violating the principle of conservatism).

One of the psychological factors that influence ethical perception is love of money. An individual who has a high love of money often has a low ethical perception which is feared to affect decision making that is less ethical in his work (Normadewi, 2012). Someone who has good ethical perception has rationality, and has good moral development, will be more rational in seeing his life needs.

\subsection{Gender}

Lucyanda and Endro (2014) state that gender is a trait inherent in men and women that is constructed socially and culturally. Purnamaningsih and Ariyanto (2016) distinguish gender in terms of masculine and feminine aspects, namely men and women. Tripermata (2016) states that men and women have different values in a work environment or learning environment. Different values and attitudes will influence differences between men and women in determining decisions and practices.

Women are more sensitive in ethics than men when defining and acknowledging ethical and unethical, and women have a better moral background and development than men. Women are more willing to fulfill their authority while men who are more aggressive and bigger have an appreciation for success than women. Men tend to have personal 
respect over social orientation. Most men are more concerned with certain competencies compared to moral affairs (Midyarany, 2016).

Men will compete to achieve success and be less concerned with the rules because they view achievement as a place to compete. In contrast to men who choose final success or relative performance, women are more concerned with self-performance. Women will prioritize the task as well as possible and harmonize work relations, so women tend to be more obedient to existing regulations and they will be more critical of individuals who violate existing rules (Sipayung, 2015).

\subsection{Locus of Control}

Lucyanda and Endro (2014) say that locus of control is someone's view of an event. The concept of locus of control comes from social learning theory (Reiss and Mitra, 1998) which states that choices are made by someone from a variety of potential behaviors that exist. Locus of control describes a person's beliefs about the relationship between these behaviors. Locus of control is divided into the internal locus of control and external locus of control. Internal locus of control refers to a person's belief in an outcome depending on the effort and hard work he does. Whereas an external locus of control refers to someone assuming that an outcome is determined by other factors outside themselves, such as fate, luck, opportunity, and other factors.

Someone with an internal locus of control generally has responsibility for the actions they take, they tend to be aware of a direct relationship between behavior and results. To get the results, they tend to impose responsibility for results on themselves so that they have more ethical perception. Conversely, someone who has an external locus of control tends to bestow responsibility for the actions he performs on factors outside of him. They tend to impose responsibility for results on others or situational factors such as luck and opportunity (Ustadi and Utami, 2005).

Evidence from the whole states that individuals who have an internal locus of control generally have better performance. They will be more active in seeking information before deciding and are more motivated to achieve and make greater efforts to control their environment (Ustadi and Utami, 2005).

\subsection{Love of Money}

Money is an aspect whose existence cannot be separated in life. Because money is very important. With money, someone can fulfill their needs, namely clothing, food, and shelter. Tang (1992) produced the theory of love of money as psychological literature. The theory aims to measure one's love of money. Love of money is a person's behavior on money and one's wishes and aspirations for money. A person's love for money means love in the form of material, can be in the form of objects or other tangible goods obtained by using their money (Tang \& Chen, 2008).

According to Tang and Chen (2008) also say the relationship of love of money is directly related to unethical behavior. When the deviation is one step to meeting the needs of getting money, people will justify their cheating easily. People who are subject to all kinds of temptations trigger them to behave ethically or unethically. Tang (1992) introduced the concept of love of money which was developed from the Money Ethic Scale (MES) with prediction factors namely good, evil, achievement, respect, budget, and freedom.

\subsection{Economic Status}

Economic status is a measure of a person's position based on his job, income, and membership in a social gathering. According to Prasastianta (2011), economic status is the position of a person or family in community life based on monthly income. Economic status can be seen from income adjusted for the price of basic goods (Owens 2004). Economic status is likely to be a form of family lifestyle. Adequate family income will support children's development. Because parents can provide primary and secondary children's needs (Conger, Conger, and Martin 2010). Besides economic status is a composite measure of the economic and social position of individuals or families relative to others, based on income, education, and employment. When analyzing family economic status, education, and the work of mothers and fathers being examined, and income combined compared with individuals, when their attributes are assessed (Conger et al. 2010).

Prasastianta (2011) tested the factors that drive economic behavior, one of the factors is the economic status of students. The results of this study indicate that the higher a person's economic status, the more he tends to behave consumptively. A person's socioeconomic status is also related to his ethical behavior. Usually, someone who has a high socioeconomic status tends to behave unethically because the social status that is owned makes him think only of his interests. The high socioeconomic status will produce a high level of love of money. 


\section{Hypotheses Development}

\subsection{Gender and Students Ethical Perception}

Gender differences can form the different perception that affects attitudinal differences between men and women in responding to cases involving professional ethics of accountants (Widyaningrum 2014). Tripermata (2016) says that men and women have different values in a work environment and learning environment. Where different values and attitudes will affect men and women in determining decisions and practices. Men tend to compete to get success and do everything including violations of existing rules because men perceive that achievement is a competition. Whereas women tend to carry out their work and duties well and have a harmonious working relationship so that women are more obedient to existing regulations. Thus,

\section{H1: Gender significantly affects students ethical perception}

\subsection{Locus of Control and Students Ethical Perception}

Locus of control is one of the personality variables, which is defined as the individual's belief in the ability to control destiny (Kreitner and Kinicki, 2005). Individual locus of control reflects a person's level of confidence in the extent to which their behavior or actions affect their success or failure. Robbins and Judge (2008) define control loci as the degree to which individuals believe that they are determinants of their destiny. According to Rotter (1990), locus of control is an individual's perception of an event, whether or not an individual can control an event. Locus of control is an individual's perspective on things that cause success or failure of the individual in carrying out activities (Hejele and Zeigler in Raiyani and Saputra, 2014). In the research Fatmawati (2007) states that locus of control does not influence one's ethical behavior. Therefore,

\section{H2: Locus of control significantly affects students ethical perception}

\subsection{Love of Money and Students Ethical Perception}

A person's perception is influenced by his ethics. The higher the ethics that is owned, the level of love for the money he has tends to be lower (Elias and Farag 2010). Love of money is closely related to greed (Tang and Chiu, 2003). Although money is used universally, the importance of money is not universally accepted (McClelland, 1967). In the process of socializing money, it is learned through the stages of the socialization process from childhood to adulthood. In the business world, managers use the money to motivate their employees (Milkovich and Newman, 2002). Udin, Handayani, \& Yuniawan (2018) emphasize that money can motivate employees, but it depends on the context and type of work.

The relationship between love of money and unethical behavior has been investigated in various countries (Tang and Chiu, 2003) arguing that the love of money has a significant impact on unethical behavior, they find the variable love of money as the root of evil. Whereas the research conducted by Luna-Arocas and Tang (2004) has the opposite results, they concluded that love of money proved not to motivate professors in the United States and Spain to take unethical actions. Therefore,

\section{H3: Love of money significantly affects students ethical perception}

\subsection{Economic Status and Students Ethical Perception}

Differences in large economic status can be formed based on different perception. This happens because of differences in family income for each student, there is always a debate regarding the income gap in each individual. According to McKinney, Legette-Traylor, Kincade, and Holloman (2004), people who have lower social classes tend to be dishonest in negotiations, break rules to get prizes, make unethical decisions, and other unethical behaviors, than those who come from economy class higher. People with low social status also tend to lie and cheat. Therefore,

\section{H4: Economic status significantly affects students ethical perception}

\section{Research Methodology}

This study uses primary data by distributing questionnaires to the students of accounting program (bachelor degree) of higher education in Semarang - Indonesia. Purposive sampling is used to select 104 respondents to participate in the study with the following predetermined characteristics. The sample criteria used are students in the final semester who have taken courses in Islamic Business Ethics and Auditing.

\subsection{Measurement}

Measurement of ethical perception is taken from the study of Tsui and Gul (1996) who used case studies that occurred in a public accounting firm (KAP). The assessment of ethical perception indicators is five questions 
regarding students' perception of scenarios in the form of related cases in the accounting field. Referring to the study of Lucyanda and Endro (2014), gender is measured using a dummy scale, where female is given a code 1 and male is given a code 2. Measurements of locus of control using the Work Locus of Control (WLC) instrument developed by Rotter (1990). The measurement of love for money uses a Money Ethic Scale developed by Tang (1992). Socio-economic status further is measured based on the classification of Vlismas, Stavrinos, and Panagiotakos (2009).

Data is analyzed using multiple linear regression with applying for IBM SPSS 21 program.

\section{Results and Discussion}

Out of the 104 respondents in this study, accounting students of male sex are $46(44.2 \%)$ and those of female is 58 (55.8\%). Respondents who have income of $<\mathrm{Rp} \mathrm{1,000,000} \mathrm{are} 26$ (25.0\%), Rp 1,000,000 - Rp 2,000,000 are 40 (63.5\%), and those who have income > Rp 2,000,000 are 38 (11.5\%). Respondents who have their income are 6 students while 98 students still share the income of parents.

\subsection{Validity Testing}

The validation of each variable is done with the results of the Pearson Correlations. It shows that all dimensions of the study are declared valid because they already have a value of significance $<0.05$.

\subsection{Reliability Testing}

Reliability testing of each dimension is carried out using the Cronbach Alpha. The calculation result of locus of control (X2) is 0.725 , love of money $(\mathrm{X} 3)$ is 0.899 , and ethical perception (Y) is 0.769 . Thus, all variables get a calculated value $>0.70$ so that they are declared reliable.

Table 1. Descriptive Statistic

\begin{tabular}{cccc}
\hline & Mean & Std. Deviation & $\boldsymbol{N}$ \\
\hline Ethical Perception & 11.7308 & 3.69263 & 104 \\
Gender & 1.4423 & 0.49907 & 104 \\
Locus of Control & 15.3077 & 2.80802 & 104 \\
Love of Money & 51.7115 & 9.23551 & 104 \\
Economic Status & 2.7115 & 1.23597 & 104 \\
\hline
\end{tabular}

Table 1 shows that gender has an average value of 1.4423 and the data distribution rate is 0.4997 ; locus of control has 15.3077 and 2.80802; love of money has 51.7115 and 9.23551; economic status has 2.7115 and 1.23597; and ethical perception has 2.7115 and 1.23597 .

\subsection{Coefficient Determination $\left(R^{2}\right)$ Testing}

The Adjusted R Square value is 0.123 . This means that $12.3 \%$ of the independent variables can explain the dependent variable. Gender, locus of control, love of money and economic status can explain the ethical perception of accounting students, while $87.7 \%$ is explained by other variables that are not examined in this study such as Machiavellian, moral reasoning, ethnic background, and level of education. Elements of behavior can not be controlled from someone, so that external factors are very varied influence a person's ethical behavior.

\subsection{Hypotheses Testing}

Hypothesis testing carried out by using multiple linear regression analysis. Data is analyzed using multiple linear regression with applying for IBM SPSS 21 program.

Table 2. Hypotheses Testing

\begin{tabular}{cccccc}
\hline Model & \multicolumn{2}{c}{$\begin{array}{c}\text { Unstandardized } \\
\text { Coefficients }\end{array}$} & $\begin{array}{c}\text { Standardized } \\
\text { Coefficients }\end{array}$ & T & Sig. \\
\cline { 2 - 6 } & $B$ & Std. Error & Beta & & \\
\cline { 2 - 6 } (Constant) & 6.358 & 2.876 & & 2.211 & 0.029 \\
Gender & 2.682 & 0.712 & 0.363 & 3.766 & 0.000 \\
Locus of Control & 0.287 & 0.129 & 0.218 & 2.218 & 0.029 \\
Love of Money & -0.072 & 0.038 & -0.180 & -1.895 & 0.061 \\
Economic Status & 0.307 & 0.277 & 0.103 & 1.111 & 0.269 \\
\hline
\end{tabular}


The test results of $\mathrm{H} 1$ indicate that gender has a significant value of $0.000<0.05$ and $\mathrm{t}$ value is 3.766 . Based on the data obtained, it can be explained partially that gender affects students' ethical perception. This shows the fact that the gap between male and female still exists even if seen from the Gender Empowerment Index continues to increase in each year. There are differences between male and female in doing a job or in appreciating the various situation of life. The pattern of thinking of female is different from male, including the courage to act and take risks. In dealing with situations where there is unethical behavior, female tends to be more careful in acting and making decisions. This result is in line with Widyaningrum (2014) that there are differences in perception between male and female. Charismawati (2011) states that in the gender socialization approach between male and female will bring different norms and values in their workplace. The cause of differences in gender between male and female is in shaping career interests, decisions and their application.

The test results of $\mathrm{H} 2$ indicate that internal locus of control has a significant value of $0.029<0.05$ and $\mathrm{t}$ value of 2.218. Based on the data obtained, it can be explained partially that internal locus of control has a positive effect on students' ethical perception. Students who have a good internal locus of control can control good events. Belief in working well will bring good results also. Someone who has an internal locus of control can behave ethically. This result is supported by Yovita and Rahmawaty (2017) that internal locus of control has a positive effect on students' ethical perception. Someone who has a high internal locus of control will try to do good actions to get good results.

The test results of $\mathrm{H} 3$ show that love of money has a significant value of $0.061>0.05$ and $t$ value of -1.895 . Based on the data obtained, it can be explained partially that love of money has a negative effect on students' ethical perception. This result is in line with Tang, Luna-Arocas, \& Sutarso (2005) that the higher the love of money, he/she will have better ethical considerations following job satisfaction. This is not following the research conducted by Charismawati (2011) that love of money and ethical perception have a negative bond. The higher the level of love of money someone has, the lower the ethical perception they have. In this study, the effect of love of money does not reduce students' ethical considerations because accounting students are given learning about the importance of valuing currency values. This becomes the basis for increasing the love of money of someone with ethical considerations in measuring an act.

The test results of $\mathrm{H} 4$ indicate that economic status has a significant value of $0.269>0.05$ and $t$ value of 1.111. Based on the data obtained, it can be explained partially that economic status does not affect students' ethical perception. This result is supported by Vlismas, Stavrinos, and Panagiotakos (2009) that economic status does not affect the ethical perception of accounting students. This study is not following the results of Saifi and Mehmood (2011) that socioeconomic status and family involvement are very important factors in student academic performance. The results of this study indicate that the level of economic status does not affect the high and low ethical perception. Students who have low economic status do not necessarily have low ethical perception. Likewise, students who have high economic status may not necessarily have high ethical perception. This happens because ethical perception arises from the character and attitude of each individual. For example, the number of corruption cases is often carried out by people who have high economic status but their ethical perception is low. All of that can happen because of the lack of feeling possessed by individuals.

\section{Conclusion}

The results of this study concluded that gender and internal locus of control have a positive effect on students' ethical perception. Love of money further has a negative effect on students' ethical perception. In contrast to the expectation, economic status does not affect students' ethical perception.

The limitations of this study are as follows:

1. Following the theory of planned behavior that a person's attitude depends on what they think. Therefore, economic status is not a determinant of one's actions but it is based on personality that forms perception.

2. The sample of this study is limited to accounting students (bachelor degree) of higher education in Semarang. It cannot yet represent the perception of the actual accounting profession.

Some suggestions given for further research are as follows:

It is recommended to add demographic factors that can affect students' ethical perception such as age and education level.

1. It is suggested to add variable personality factors that can affect students' ethical perception such as Machiavellian and moral reasoning. 
2. It is recommended to expand the sample, namely in people who work as accountants. Because in this study, respondents only included undergraduate accounting students.

\section{References}

Accounting Education Change Commission (AECC), A. E. C. C. (1990). Objective of Education for Accountants: Position Statement Number One. Issues in Accounting Education (Fall), 307-312.

Basri, Yesi Mutia. (2015). Pengaruh Gender, Religiusitas Dan Sikap Love Of Money Pada Persepsi Etika Penggelapan Pajak Mahasiswa Akuntasi. Jurnal Ilmiah Akuntansi Dan Bisnis. https://ojs.unud.ac.id/index.php/jiab/article/view/16818.

Chan, S. Y. \& Leung, P. (2006). The effects of accounting students' ethical reasoning and personal factors on their ethical sensitivity. Managerial auditing journal, 21(4), 436-457. https://doi.org/10.1108/02686900610661432.

Charismawati, C. D. (2011). Analisis Hubungan Antara Love of Money dengan Persepsi Etis Mahasiswa Akuntansi. Skripsi Universitas Diponegoro. http://eprints.undip.ac.id/29310/.

Conger, Rand D., Katherine J. Conger \& Monica J. Martin. (2010). Socioeconomic Status, Family Processes, and Individual Development. Journal of Marriage and Family. https://doi.org/10.1111/j.1741-3737.2010.00725.x.

Elias, Rafik Z. \& Magdy Farag. (2010). The Relationship between Accounting Students' Love of Money and Their Ethical Perception. Managerial Auditing Journal. https://doi.org/10.1108/02686901011026369.

Fatmawati, N. D. (2007). Analisis Pengaruh Faktor-faktor Individual terhadap Perilaku Etis Audiot di KAP. Skripsi Universitas Muhammaddiyah Surakarta. http://eprints.ums.ac.id/11516/.

Fatoki, Olawale. (2015). Gender, Academic Major and the Love of Money by University Students in South Africa. Gender \&

Behaviour. https://www.ingentaconnect.com/content/sabinet/genbeh/2015/00000013/00000001/art00019.

Himmah, Elok Faiqoh. (2018). Persepsi Etis Mahasiswa Akuntansi Mengenai Skandal Etis Auditor Dan Corporate Manager. Jurnal Akuntansi Multiparadigma. http://dx.doi.org/10.18202/jamal.2013.04.7180.

Lucyanda, Jurica \& Gunardi Endro. (2014). Faktor-Faktor Yang Mempengaruhi Perilaku Etis Mahasiswa Akuntansi Universitas Jember. Jurnal Ekonomi Dan Ilmu Sosial Universitas Bakrie. http://journal.bakrie.ac.id/index.php/journal_MRA/article/view/272.

Luna-Arocas, R. \& Tang, T. L. P. (2004). The love of money, satisfaction, and the protestant work ethic: Money profiles among univesity professors in the USA and Spain. Journal of business ethics, 50(4), 329-354. https://doi.org/10.1023/B:BUSI.0000025081.51622.2f

Kreitner \& Kinicki. (2005). Perilaku Organisasi, (buku 1). Jakarta: Salemba Empat.

McClelland, D. C. (1967). Achieving society, 92051, Simon and Schuster.

McKinney, L. N., Legette-Traylor, D., Kincade, D. H. \& Holloman, L. O. (2004). Selected social factors and the clothing buying behaviour patterns of black college consumers. The International Review of Retail, Distribution and Consumer Research, 14(4), 389-406. https://doi.org/10.1080/0959396042000260861.

Midyarany, D. (2016). Pengaruh Sensitivitas Etis, Gender, dan Locus of Control Terhadap Perilaku Etis Mahasiswa. Sekolah Tinggi Ilmu Ekonomi Indonesia (STIESIA) Surabaya.

Milkovich, G. T. \& Newman, J. M. C. (2002). Compensation, 8, McGraw-Hill New York.

Mintz, S. M. (1995). Virtue ethics and accounting education. Issues in Accounting Education, 10, 247-268.

Normadewi, B. (2012). Analisis Pengaruh Gender dan Tingkat Pendidikan Terhadap Persepsi Etis Mahasiswa Akuntansi dengan Love of Money Sebagai Variabel Intervening. Skripsi Universitas DIponegoro.

O'Leary, Conor. \& Derry, Cotter. (2000). The Ethics of Final Year Accountancy Students: An International Comparison. Managerial Auditing Journal. https://doi.org/10.1108/02686900010319366.

Owens, J. D. \& McLeod dan, T. J. (2004). Psychologist Well-Being The Early Lite Courses: Variation by Sosipeconomics Status Gender, and Estimacty. Social Psychology Quarterly, 3, 257-78. https://doi.org/10.1177/019027250406700303.

Pradanti, Noviani Rindar \& Andri Prastiwi. (2014). Analisis Pengaruh Love of Money Terhadap Persepsi Etis Mahasiswa Akuntansi. http://eprints.undip.ac.id/43623/. 
Prasastianta, D. (2011). Pengaruh Minat Pada Pembelajaran Ekonomi, Status Sosial Ekonomi Orang Tua, Pengetahuan Ekonomi dan Rasionalitas Ekonomi Terhadap Perilaku Ekonomi. Skripsi tidak dipublikasikan. Fakultas Ekonomi Universitas Negeri Makasar .

Purnamaningsih, Ni ketut Ayu and Dodik Ariyanto. (2016). Pengaruh Gender, Usia, Tingkat Pendidikan, Dan Status Sosial Ekonomi Terhadap Persepsi Etis Mahasiswa Akuntansi. E-Jurnal Akuntansi Udayana. https://ojs.unud.ac.id/index.php/Akuntansi/article/view/19875.

Raiyani, N. L. K. P. \& Suputra, I. D. (2014). Pengaruh Kompetensi, Kompleksitas Tugas, dan Locus of Control terhadap Audit judgment. E-Jurnal 429-438. https://ojs.unud.ac.id/index.php/Akuntansi/article/view/8335.

Reiss, M. \& K. Mitra. (1998). The Effects of Individual Difference Factors on The Acceptability of Ethical and Workplace Behaviours. Journal of Business Ethics, 1581-93. https://doi.org/10.1023/A:1005742408725

Robbins, Stephen P. \& Timothy A. Judge. (2008). Perilaku Organisasi Organizational Behavior. Jakarta: Salemba Empat.

Rotter, J. B. (1990). Internal versus external control of reinforcement: A case history of a variable. American psychologist, 45(4), 489. https://doi.org/10.1037/0003-066X.45.4.489

Saifi, S. \& Mehmood, T. (2011). Effects of socio-economic status on students achievement. International Journal of Social Sciences and Education, 1(2), 119-128.

Sipayung, E. R. (2015). Analisis Pengaruh Aspek Demografi, Status Sosial Ekonomi dan Pengalaman Kerja Terhadap Persepsi Etis Mahasiswa Akuntansi dengan Love of Money Sebagai Variabel Intervening. Skripsi Universitas Diponegoro.

Tang, T. L. P. (1992). The meaning of money revisited. journal of Organizational Behavior, 13(2), 197-202. https://doi.org/10.1002/job.4030130209.

Tang, T. L. P. \& Chen, Y. J. (2008). Intelligence vs. wisdom: The love of money, Machiavellianism, and unethical behavior across college major and gender. Journal of business ethics, 82(1), 1-26. https://doi.org/10.1007/s10551-007-9559-1

Tang, T. L. P. \& Chiu, R. K. (2003). Income, money ethic, pay satisfaction, commitment, and unethical behavior: is the love of money the root of evil for Hong Kong employees? Journal of business ethics, 46(1), 13-30. https://link.springer.com/article/10.1023/A:1024731611490.

Tang, T. L. P., Luna-Arocas, R. \& Sutarso, T. (2005). From income to pay satisfaction: The love of money and pay equity comparison as mediators and culture (the United States and Spain) and gender as moderators. Management Research: Journal of the Iberoamerican Academy of Management, 3(1), 7-26. https://doi.org/10.1108/15365430580001311.

Tripermata, Lukita. (2016). Pengaruh Love of Money, Perilaku Etis Mahasiswa Dan Kecurangan Akuntansi Dengan Gender. Jurnal Ilmiah Ekonomi Global Masa Kini, $7(1)$. http://ejournal.uigm.ac.id/index.php/EGMK/article/view/169.

Tsui, Judy S. L. \& Ferdinand A. Gul. (1996). Auditors' Behaviour in an Audit Conflict Situation: A Research Note on the Role of Locus of Control and Ethical Reasoning. Accounting, Organizations, and Society. https://doi.org/10.1016/0361-3682(95)00009-X.

Udin, Handayani, S. \& Yuniawan, A. (2018). Does money motivate people?: A summary of issues and discussion points. Journal of Engineering and Applied Sciences, 13(12), 4320-4323.

Ustadi, N. \& R. D. Utami. 2005. Analisis Perbedaan Faktor-Faktor Individual Terhadap Persepsi Perilaku Etis Mahasiswa. Jurnal Akuntansi \& Auditing, 1(02), 162-80. http://eprints.undip.ac.id/13861/.

Vlismas, K., Stavrinos, V. \& Panagiotakos, D. B. (2009). Socio-economic status, dietary habits and health-related outcomes in various parts of the world: a review. Central European journal of public health, 17(2). https://doi.org/10.21101/cejph.a3475

Widyaningrum, A. (2014). Determinan Persepsi Etis Mahasiswa Akuntansi Dengan Love Of Money Sebagai Variabel Intervening. Jurnal Ilmiah Mahasiswa, 2(2). https://jimfeb.ub.ac.id/index.php/jimfeb/article/view/1024. 